\title{
Farmers' Practices and Combinations of Malathion and Neem Seed Powder Management Options on Stored Sorghum and Maize Insect Pests at Bako, West Shoa, Ethiopia
}

\author{
Ahmed Ibrahim \\ Ethiopian Institute of Agricultural Research, Melkassa Agricultural Research Center, P.O. Box: 436,
} East Shoa Melkassa, Ethiopia

\begin{tabular}{|c|c|}
\hline Abstract & Article Information \\
\hline $\begin{array}{l}\text { Some farmers' practices (layering of tef over sorghum with } 20 \% \text { proportion, mixing sorghum } \\
\text { with tef at } 30 \% \text { w/w, mixing sorghum with partially grindedhot pepper at the rate of } 2 \% \text { w/w and } \\
1 \% \text { w } / w \text { ) including Malathion } 5 \% \mathrm{D} \text { and untreated check were evaluated against stored } \\
\text { sorghum insect pests at Bako Research Center, Western Ethiopia, from } 2010 / 11-2011 / 12 \mathrm{G} \text {.C. } \\
\text { Besides, combinations of different rates of Malathion } 5 \% \mathrm{D} \text { and neem seed powder were } \\
\text { evaluated against maize weevils in the laboratory at Bako from February - July } 2012 \text {. Number } \\
\text { and weight of damaged grains significantly (p<0.05) higher in layering of tef over sorghum with } \\
20 \% \text { w/w, mixing sorghum with tef at } 30 \% \text { w/w and untreated check than the other treatments. } \\
\text { Similarly, percent weight losses significantly }(\mathrm{p}<0.05) \text { lower in mixing sorghum with hot pepper } \\
\text { at } 2 \% \text { and } 1 \% \text { w } / \mathrm{w} \text { than the other treatments, which was similar to standard check. As to } \\
\text { combine treatments, mortality in all of the treatment combinations ranged from } 3.33-100 \% \text {, } \\
\text { while that of the untreated check ranged from } 0-5.33 \% \text { following } 90 \text { days after infestation. } \\
\text { Similarly, the number of progeny weevils emerged, percentages of grain damaged and seed } \\
\text { weight losses in all of the treatment combinations were significantly lower than that of the } \\
\text { untreated check } 90 \text { days after infestation. Significantly (P<0.05) higher percentages of } \\
\text { mortality, lower percentages of damaged grains and seed weight losses were observed in the } \\
\text { Malathion dust at } 40 \% \text { and } 50 \% \text { combined with neem seed powder than that of the other } \\
\text { treatments next to the standard check } 156 \text { days after infestation. From these studies, it can be } \\
\text { concluded that mixing sorghum with partially grinded hot pepper at the rate of } 2 \% \text { w/w and } 1 \% \\
\text { w/w can be used to protect stored sorghum insect pests and combinations of malathion and } \\
\text { neem seed powder at } 40 \%+20 \% \text { and } 50 \%+10 \% \text { can be used to protect maize from the maize } \\
\text { weevil. } \\
\text { Copyright@2015 STAR Journal, Wollega University. All Rights Reserved. }\end{array}$ & $\begin{array}{l}\text { Neem seed powder } \\
\text { Farmers practices Malathion } \\
5 \% \mathrm{D}, \\
\text { Stored sorghum } \\
\text { Maize insect pest } \\
{ }^{\star} \text { Corresponding Author: } \\
\text { Ahmed Ibrahim } \\
\text { E-mail: } \\
\text { ibrahimyuya02@gmail.com }\end{array}$ \\
\hline
\end{tabular}

\section{INTRODUCTION}

The absence of maize and sorghum storage insect pest management technologies forces the growers to sell their produces immediately after harvest (Abraham, 1991; Emana and Assefa, 1998). Consequently, farmers receive low market prices for surplus grain they produce (Abraham, 1991; Beyene et al., 1996). Although the use of pesticides are one means of protecting stored grain, the associated side effects on the environment and human health, development of genetically resistance insect strains, erratic supply and prohibitive costs have become a major concern and thus given imputes to the search for alternative methods of pest control (Abraham, 1991). Various methods are used to control storage pests by farmers in sorghum and maize producing areas such as mixing sorghum and maize with small seeded cereals such as tef and finger millet. Others were observed to mix the produce with partially grindedhot pepper. A sort of layering by putting one crop over the other, the produce that is liable to attack being in the middle and the other at bottom and upper portion is also practiced by some farmers. All these methods of storage pest control options seem to be good for the control of stored sorghum or maize pests but they were not proved for efficacy. Farmers' practices should be supported by research, as their adoption rate could be very high and for wider applicability.

In addition, use of locally available plant products and vegetable oils are other options to reduce reliance on synthetic chemicals. A major limitation to the practical utilization of locally available plant products and vegetable oil are their high rates required to effectively disinfest grains (Don-Pedro, 1989). The possibility of using reduced levels of plant products in combination with each other in simple mixtures as a means of making their use may be more attractive and effective (Don-Pedro, 1989). Integrating one control strategy with another sustainable pest control method would and may provide long lasting solution to losses in storage for the reason of their synergetic effects (Dobie, 1977). The importance of 


\section{Ahmed lbrahim}

combining two or more control options may minimize risk and costs of chemical, reduce resistance development against the treatments and increases effectiveness of the treatments.

Therefore, the objectives of the studies were to evaluate the effectiveness of some pest control practices used by farmers in controlling stored sorghum and maize insect pest, to determine the combined effects of malathion dust and neem seed powder against the maize weevil, Sitophilus zeamais Mostch. on maize and to determine the minimum effective rate(s) of the combinations that can provide adequate protection to maize against the pest.

\section{MATERIALS AND METHODS}

Two experiments were conducted at Bako Agricultural Research Center, West Shoa, Bako. The first experiment was conducted from 2010/11 -2011/12 GC cropping seasons on traditional but modified storage structures (gotera) and the second was also conducted from February to July 2012 GC in the laboratory at Bako Agricultural Research Center.

\section{Evaluation of Some Farmers' Practices against Stored Sorghum Insect Pests in Field Conditions}

Twenty-seven quintals (27) of sorghum (local variety Bobe) and three (3) quintals of tef were used to conduct a year experiment. Six treatments (Layering of tef over sorghum with $20 \% \mathrm{w} / \mathrm{w}$, Mixing with tef at $30 \% \mathrm{w} / \mathrm{w}$, Mixing with partially grindedchilies (hot pepper) at the rate of $2 \% \mathrm{w} / \mathrm{w}$,Mixing with partially grinded chilies (hot pepper) at the rate of $1 \% \mathrm{w} / \mathrm{w}$, Insecticide (malathion $5 \%$ D) at the rate of $50 \mathrm{~g} / \mathrm{qt}$ and Control) were evaluated against stored sorghum insect pests.

The experiment was laid out in randomized complete block design replicated three times. Plastic sheets were used to separate sorghum from tef in the layering treatments. Sample size of $350 \mathrm{gm}$ /plot or gotera was taken from each treatment using compartmented spear and assess the parameters from each treatment. Data were collected for number of live and dead insects infesting the grain in each treatment, number of damaged and undamaged grains, weight of damaged and undamaged grains and percent weight losses/sample. Evaluation was made after 60,120 and 180 days of storage. Percent weight losses were calculated by using the following formula:

$$
\% \text { Weight loss }=\frac{(\mathrm{Wu} \times \mathrm{Nd})-(\mathrm{Wd} \times \mathrm{Nu})}{\mathrm{Wu} \times(\mathrm{Nd}+\mathrm{Nu})} \times 100
$$

Where, $\mathrm{Wu}=$ Weight of undamaged grains, $W D=$ Weight of damaged grains, Nu=Number of undamaged grains, $\mathrm{Nd}=$ Number of damaged grains. Combined analysis was done for two years (2003/2004 and 2004/2005) using SAS version 6.12 computer software

\section{Efficacy of Malathion 5\% D with Neem Seed Powder against Sitophilus zeamais on Stored Maize in the Laboratory}

\section{Preparation of Experimental Materials}

Maize hybrid $\mathrm{BH}-540$ was obtained from the BARC maize research program and multiplied in the center to obtain the $F_{2}$ generation seeds in sufficient amount for the experiments. Neem seed powder was obtained from
Sci. Technol. Arts Res. J., Jan-March 2015, 4(1): 50-56

Melka worer research center. Malathion 5\% D was purchased from the market.

\section{Establishments of Culture of Weevils}

Maize weevils were collected from the Bako Agricultural Research Center maize store and reared in the laboratory where the experiment was conducted. The weevils were cultured on $\mathrm{BH}-540$ maize hybrid which is most commonly grown by local farmers. Seeds were cleaned and kept in a deep freezer at $-20 \pm 2^{\circ} \mathrm{C}$ for two weeks in order to disinfest. The seeds were then kept for two weeks at the experimental conditions for acclimatization (Abraham, 2003) and adjusted to moisture content of 12 to $13 \%$ before use by absorption of atmospheric humidity. Two kg seeds were placed in three liter plastic containers covered with perforated lids. About 600 unsexed adult weevils were introduced into each of the plastic containers. After two weeks of oviposition, all adult weevils were removed, and the seeds were kept for progeny emergence. The average developmental time of the maize weevil on maize in the laboratory condition is about 42 days (Abraham, 1991). Therefore progeny emergence was monitored daily and those emerged on the same day were transferred to fresh seed in plastic containers with lids and kept under the experimental conditions until a sufficient number of weevils was obtained.

\section{Applications of the Treatments}

Maize kernels were cleaned and disinfested following the same procedure as above. The moisture content of the kernels was adjusted by slow drying under shade or by adding water as recommended by Wright et al. (1989). Two hundred gram maize kernels were put in $250 \mathrm{~cm}^{3}$ capacity glass jars with brass screen lids that permit ventilation. The treatments $(0 \%(0 \mathrm{gm})+100 \%(4 \mathrm{gm})$, $10 \%(0.01 \mathrm{gm})+50 \%(2 \mathrm{gm}), 20 \%(0.02 \mathrm{gm})+40 \%$ (1.6 gm), 30\% (0.03 gm) +30\% ( $1.2 \mathrm{gm}), 40 \%(0.04 \mathrm{gm})$ $+20 \%$ ( $0.8 \mathrm{gm}), 50 \%$ (0.05 gm) $+10 \%$ ( $0.4 \mathrm{gm}), 100 \%$ $(0.1 \mathrm{gm})+0 \%$ and untreated check) were then applied to the maize kernels.

The treated maize kernels were thoroughly mixed to ensure uniform distribution of treatments. Adult maize weevils were introduced into each jar at the ratio of one weevil to two to three (1: 2-3 gm) maize kernels (50 weevils/ $200 \mathrm{gm}$ maize). The treatments were arranged in a completely randomized block design (RBD) with three replications. The temperature and relative humidity of the laboratory were recorded daily. In order to investigate the persistence of the treatments used, the same number of weevils (50 weevils/ $200 \mathrm{~g}$ seed) was re-introduced into the grain following 90 days after the treatment application. The same data were collected 156 days after reinfestation

\section{Data Collection}

Adult Weevil Mortality: Mortality was assessed 2, 4, 6, 12 , and 18 days after treatment application. The assessment periods selected were based on an earlier report by Dobie (1984). Dead adult weevils were removed and counted during each assessment.

$F_{1}$ Progeny Emergence: Thirty days after application of treatment, after removing dead and alive weevils, the seeds were kept under the same conditions to assess emergence of $F_{1}$ progenies. The number of $F_{1}$ progeny weevils emerged was recorded every day for 60 days. 


\section{Ahmed lbrahim}

Emerged adults were removed from the jar on each assessment day and continued until all progeny emerged.

Seed Damage and Weight Loss: Ninety days after the introduction of adult maize weevils, the number and weight of damaged and undamaged seeds were recorded. Seed weight loss was calculated by using the count and weigh method (Boxall, 1986).

Seed Germination: In order to assess the viability of seeds, seed germination was tested using 100 randomly picked seeds from undamaged grains after separation of damaged and undamaged grains in each jar. The seeds were placed on a moistened filter paper in plastic Petri dishes and the number of germinated seeds was recorded after ten days.

\section{Statistical Analysis}

The number of dead weevils in each replicate was converted into proportions of the total number of adult weevils introduced and expressed as percentage. Mortality data were corrected for natural control mortality using Abbott's correction formula,

$$
\% C M=\frac{(\% T-\% C)}{(100-\% C)} * 100
$$

where $\mathrm{CM}$ is corrected mortality, $\mathrm{T}$ is mortality in treated seed and $\mathrm{C}$ is mortality in untreated seed (Abbot, 1925). Control mortality did not exceed 10\%. Damaged seeds were expressed as a percentage of the total number of seeds in each replicate. Weight loss data were
Sci. Technol. Arts Res. J., Jan-March 2015, 4(1): 50-56

also expressed as percentages. Percentage mortality was angular transformed, while number of progeny weevils emerged, percentage grain damaged and grain weight losses were square root transformed prior to statistical analysis, in order to stabilize the variances. Percentage of germination was not transformed. All data were subjected to analysis of variance. Differences among means were determined using Student-Newman-Keuls Test. Backtransformed means are presented. Data were analyzed using SAS Version 6.12 computer software.

\section{RESULTS}

\section{Field Study at Bako}

Significant differences were recorded among some farmers' practices on number of weevils and Sitotroga cerealella (Oliver) dead and alive (Table 1). Significantly $(P<0.05)$ higher numbers of dead weevils were observed in the untreated check than the other treatments. Similarly number of weevils alive was significantly $(P<0.05)$ higher in the layering of tef over sorghum with $20 \% \mathrm{w} / \mathrm{w}$, mixing sorghum with tef at $30 \% \mathrm{w} / \mathrm{w}$ and in the untreated check than the other treatments. Numbers of $S$. cerealella (Oliver) dead and alive were significantly higher in the untreated check followed by layering of tef over sorghum with $20 \%$ proportions and mixing sorghum with tef at $30 \%$ w/w. However, significantly $(P<0.05)$ lower numbers of Sitotroga cerealella (Oliver) dead and alive were recorded in mixing sorghum with partially grinded hot pepper at the rate of $2 \% \mathrm{w} / \mathrm{w}$ and $1 \% \mathrm{w} / \mathrm{w}$ and in the standard check (Table 1).

Table 1: Effects of some farmers' practices, on numbers of weevil and Sitotroga dead and alive at Bako, west shoa, Ethiopia (combined ANOVA of data of 2010/11 and 2011/12 cropping seasons)

\begin{tabular}{|c|c|c|c|c|c|}
\hline & \multirow{2}{*}{ Treatments (farmers practices) } & \multicolumn{2}{|c|}{$\begin{array}{c}\text { Number of } \\
\text { weevil/sample }\end{array}$} & \multicolumn{2}{|c|}{$\begin{array}{c}\text { Number of Sitotroga/ } \\
\text { samples }\end{array}$} \\
\hline & & Dead & Alive & Dead & Alive \\
\hline 1 & Layering of tef over sorghum with $20 \% \mathrm{w} / \mathrm{w}$ & $79.54^{b}$ & $85.37^{\mathrm{a}}$ & $82.35^{\mathrm{bc}}$ & $29.94^{\mathrm{b}}$ \\
\hline 2 & Mixing with tef at $30 \% \mathrm{w} / \mathrm{w}$ & $79.71^{\mathrm{b}}$ & $84.60^{a}$ & $97.27^{\mathrm{b}}$ & $27.40^{\mathrm{b}}$ \\
\hline 3 & Mixing with partially groundchilies (hot pepper) at the rate of $2 \% \mathrm{w} / \mathrm{w}$. & $94.40^{\mathrm{b}}$ & $33.52^{b}$ & $51.78^{\mathrm{de}}$ & $3.07^{c}$ \\
\hline 4 & Mixing with partially groundchilies (hot pepper) at the rate of $1 \% \mathrm{w} / \mathrm{w}$. & $90.35^{\mathrm{b}}$ & $41.92^{\mathrm{b}}$ & $71.63^{\mathrm{cd}}$ & $3.79^{c}$ \\
\hline 5 & Insecticide (malathion $5 \% \mathrm{D}$ ) at the rate of $50 \mathrm{~g} / \mathrm{qt}$ & $97.71^{\mathrm{b}}$ & $12.25^{\mathrm{c}}$ & $33.16 \mathrm{e}$ & $0.92^{c}$ \\
\hline \multirow[t]{3}{*}{6} & Control (untreated check) & $217.56^{a}$ & $82.64^{\mathrm{a}}$ & $223.15^{\mathrm{a}}$ & $58.81^{\mathrm{a}}$ \\
\hline & $\mathrm{CV} \%$ & 10.54 & 21.16 & 15.57 & 55.22 \\
\hline & Lsd & 19.56 & 20.44 & 24.97 & 19.43 \\
\hline
\end{tabular}

Means followed by similar letter within a column are not significantly different from each other at $5 \%$ level of probability (student new man kewls range test (SNK)

Variations were observed among some farmers practices evaluated against storage insect pests of sorghum with respect to number of grains damaged and undamaged, weight of grains damaged and undamaged and percent weight losses (Table 2). Number and weight of grain damaged were significantly $(P<0.05)$ higher in the layering of tef over sorghum with $20 \% \mathrm{w} / \mathrm{w}$, mixing sorghum with tef at $30 \% \mathrm{w} / \mathrm{w}$ and in the untreated check than the other treatments. Similarly number and weight of grains undamaged were significantly higher in mixing sorghum with partially grindedhot pepper at the rate of $2 \%$ $\mathrm{w} / \mathrm{w}, 1 \% \mathrm{w} / \mathrm{w}$ and malathion $5 \% \mathrm{D}$ than the other treatments (Table 2). Percent weight losses were significantly lower in mixing sorghum with partially grindedchilies (hot pepper) at the rate of $2 \% \mathrm{w} / \mathrm{w}$ and $1 \%$ $\mathrm{w} / \mathrm{w}$, and malathion $5 \% \mathrm{D}$ than in the other treatments (Table 2). Species of insect pests infesting the free choice test treatments are indicated in the Table 3. Among the species recorded Tribolium spp, Sitophilus spp and Sitotroga cerealella (Oliver) are the most abundant species followed by Carpophilus spp and Cryptolestes spp. The other species such as Lasioderma serricorine $(\mathrm{F})$, Oryzaephilus spp and Rhizopertha dominica (F) were appeared rarely. 
Table 2: Effect of some farmers practices on number of grains damaged and undamaged, weight of grains damaged and undamaged and percent weight losses in stored sorghum insect pests at Bako, west Shoa, Ethiopia (combined ANOVA of 2010/11 and 2011/12data).

\begin{tabular}{|c|c|c|c|c|c|c|}
\hline \multirow{2}{*}{$\begin{array}{l}\text { Trt. } \\
\text { no }\end{array}$} & \multirow{2}{*}{ Treatments (farmers practices) } & \multicolumn{2}{|c|}{$\begin{array}{c}\text { Number of } \\
\text { grains/sample }\end{array}$} & \multicolumn{2}{|c|}{$\begin{array}{c}\text { Weight of } \\
\text { grains/ samples }\end{array}$} & \multirow{2}{*}{$\begin{array}{c}\text { Percent } \\
\text { weight } \\
\text { losses }\end{array}$} \\
\hline & & Damaged & Undamaged & $\begin{array}{l}\text { Damaged } \\
\quad(g m)\end{array}$ & $\begin{array}{l}\text { Undamaged } \\
\text { (gm) }\end{array}$ & \\
\hline 1 & Layering of tef over sorghum at $20 \% \mathrm{w} / \mathrm{w}$ & $421.41^{a}$ & $10472.19^{\mathrm{bc}}$ & $4.17^{\mathrm{a}}$ & $225.84^{c}$ & $2.07^{a}$ \\
\hline 2 & Mixing with tef at $30 \% \mathrm{w} / \mathrm{w}$ & $393.91^{\mathrm{a}}$ & $111150.60^{b}$ & $3.75^{\mathrm{a}}$ & $221.95^{c}$ & $1.78^{a}$ \\
\hline 3 & $\begin{array}{l}\text { Mixing with partially groundchilies (hot pepper) } \\
\text { at the rate of } 2 \% \mathrm{w} / \mathrm{w} \text {. }\end{array}$ & $216.24^{b}$ & $14300.01^{a}$ & $2.71^{\mathrm{b}}$ & $335.58^{a}$ & $0.68^{b}$ \\
\hline 4 & $\begin{array}{l}\text { Mixing with partially groundchilies (hot pepper) } \\
\text { at the rate of } 1 \% \mathrm{w} / \mathrm{w} \text {. }\end{array}$ & $208.68^{b}$ & $13300.84^{a}$ & $2.64^{b}$ & $304.83^{b}$ & $0.74^{b}$ \\
\hline 5 & Insecticide (malathion $5 \% \mathrm{D}$ ) at the rate of $50 \mathrm{~g} / \mathrm{qt}$ & $199.86^{b}$ & $14340.98^{a}$ & $2.37^{b}$ & $332.90^{\mathrm{a}}$ & $0.66^{\mathrm{b}}$ \\
\hline 6 & Control (check) & $414.14^{\mathrm{a}}$ & $9692.76^{c}$ & $4.25^{\mathrm{a}}$ & $217.69^{c}$ & $2.23^{a}$ \\
\hline & CV\% & 13.94 & 5.21 & 16.40 & 5.10 & 24.35 \\
\hline & Lsd & 73.37 & 1083 & 0.93 & 23.72 & 0.56 \\
\hline
\end{tabular}

Table 3: Species of insect pests recorded in stored sorghum at Bako Agricultural Research center/ sample

\begin{tabular}{|c|c|c|c|}
\hline Order/species & Common name & $\begin{array}{l}\text { Status/abunda-nce } \\
\text { of the pest in the storage }\end{array}$ & $\begin{array}{l}\text { Types of insect } \\
\text { Pests/beneficial }\end{array}$ \\
\hline Colleoptera & & & Pest \\
\hline Tribolium spp & Maize /rice weevils & Very common & Pest \\
\hline Sitophilus spp & Maize /rice weevils & Very common & Pest \\
\hline Carpophilus spp & Sap beetles & Common & Pest \\
\hline Cryptolestes spp. & Flat grain beetles & Common & Pest \\
\hline Lasioderma serricorine $(F)$ & Saw toothed grain beetles & Rare & Pest \\
\hline Oryzaephilus spp & Lesser grain borer & Rare & Pest \\
\hline Rhizopertha dominica $(F)$ & Red/confused flower beetles & Rare & \\
\hline Lepidoptera & & & Pest \\
\hline Sitotroga cerealella (Oliver) & Angoumois grain moth & Very common & \\
\hline Hymenoptera & & & Beneficial \\
\hline \multicolumn{4}{|l|}{ Parasitic wasp } \\
\hline Archnida & & & \\
\hline Acarus siro $(L)$ & Flour mite & & Pest \\
\hline
\end{tabular}

\section{Laboratory Study at Bako}

Combinations of different rates of Malathion dust and neem seed powder caused higher mortality than the untreated control (Table 4). The parent weevil mortality was significantly $(P<0.01)$ higher in $\mathrm{T}_{5}, \mathrm{~T}_{6}$ and in the standard check than that of the other treatments following two and four days after infestation. Six days after infestation, the percentages of mortality were significantly lower in $T_{2}$ and $T_{3}$ than the other treatment combinations and followed by $T_{5}$ and $T_{6}$. The rates of weevil mortality reached $100 \%$ in $T_{1}, T_{4}, T_{5}, T_{6}$ and $T_{7}$ after 12 dai (Table 4). However, $48 \%$ and $66 \%$ of mortality were recoded in $\mathrm{T}_{3}$ and $\mathrm{T}_{2}$, respectively, following 12 dai and the difference between these treatments was significant. The rates of mortality reached $100 \%$ in all of the treatments except for the untreated check following 18 dai (Table 4). The number of progeny weevils emerged, percentages of grain damaged and grain weight losses recorded in the combined treatments were significantly lower than that in the untreated control (Table 5). The differences among the treatment combinations were not significant for the indicated parameters (Table 5). Significant differences were observed in weevil mortality among the different combinations of Malathion dust and neem seed powder (Table 6). The percentages of mortality were significantly higher in $T_{5}$ and $T_{6}$ than that of the other treatment combinations following all of the days considered.
Mortality in the untreated check was the lowest. The percentages of mortality were significantly lower in $T_{2}, T_{3}$ and $T_{4}$ than $T_{5}$ and $T_{6}$ following two, four, six and 12 days after infestation. Following 18 dai, the rate of mortality $T_{2}$, $T_{3}$ and $T_{4}$ was significantly lower than in all of the other combinations (Table 6). Different rates of Malathion dust and neem seed powder combinations had varying degree of residual effects in terms of the number of progeny weevil emergence, percentage of grain damaged, grain weight losses and seed germination (Table 7). The number of progeny weevil emergence, percentages of grain damaged and grain weight losses in all treatments were significantly $(P<0.01)$ lower than neem seed powder alone and in the untreated check. The neem seed powder treatment was found to be weak in stopping the development progeny weevils as it was with the second large progeny emerged. The lowest progeny emergence and seed damage were recorded in $\mathrm{T}_{7}$ (Table 7 ). The number of progeny weevils emerged, percentages of grain damaged and grain weight losses were significantly lower in $T_{5}$ and $T_{6}$ than $T_{1}, T_{2}, T_{3}$ and $T_{4}$. The differences among $T_{2}, T_{3}$ and $T_{4}$ as well as between $T_{5}$ and $T_{6}$ were not significant for the above-mentioned parameters. The percentages of seed germination were significantly $(p<0.01)$ higher in all of the treatments than in the untreated check (Table 7). 
Table 4: The effects of different rates of Malathion $5 \% \mathrm{D}$ and neem seed powder combinations on weevil mortality

\begin{tabular}{|c|c|c|c|c|c|}
\hline \multirow{2}{*}{ Treatment } & \multicolumn{5}{|c|}{ Percent weevil mortality } \\
\hline & 2 dai & 4 dai & 6 dai & 12 dai & 18 dai \\
\hline $\mathrm{T}_{1}$ & $3.33(10.4) \pm 0.67^{d}$ & $8.67(19.05) \pm 0.67^{c}$ & $87.33(69.24) \pm 1.33^{b}$ & $100.00(89.50) \pm 0.00^{a}$ & $100.00(89.50) \pm 0.00^{a}$ \\
\hline $\mathrm{T}_{2}$ & $3.33(10.4) \pm 0.67^{d}$ & $18.67(24.53) \pm 3.27^{\mathrm{bc}}$ & $45.33(42.31) \pm 4.4 c^{d}$ & $66.00(59.46) \pm 5.02^{\mathrm{b}}$ & $100.00(89.50) \pm 0.00^{a}$ \\
\hline $\mathrm{T}_{3}$ & $5.33(13.3) \pm 0.67^{c}$ & $10.00(18.38) \pm 1.15^{c}$ & $36.67(37.28) \pm 0.67^{d}$ & $48.00(43.87) \pm 1.15^{\mathrm{c}}$ & $100.00(89.50) \pm 0.00^{a}$ \\
\hline $\mathrm{T}_{4}$ & $3.33(10.4) \pm 0.67^{d}$ & $10.67(19.05) \pm 0.67^{c}$ & $86.00(68.09) \pm 1.15^{b}$ & $100.00(89.50) \pm 0.00^{a}$ & $100.00(89.50) \pm 0.00^{a}$ \\
\hline $\mathrm{T}_{5}$ & $12.00(20.23) \pm 1.15^{b}$ & $31.33(34.05) \pm 0.67^{\mathrm{b}}$ & $56.67(48.85) \pm 0.69^{c}$ & $100.00(89.50) \pm 0.00^{a}$ & $100.00(89.50) \pm 0.00^{a}$ \\
\hline $\mathrm{T}_{6}$ & $10.67(19.05) \pm 0.67^{b}$ & $32.00(34.45) \pm 4.16^{\mathrm{b}}$ & $57.33(49.26) \pm 4.05^{c}$ & $100.00(89.50) \pm 0.00^{a}$ & $100.00(89.50) \pm 0.00^{a}$ \\
\hline $\mathrm{T}_{7}$ & $22.67(28.44) \pm 0.67^{a}$ & $77.33(61.60) \pm 0.67^{a}$ & $100.00(89.50) \pm 0.00^{a}$ & $100.00(89.50) \pm 0.00^{a}$ & $100.00(89.50) \pm 0.00^{a}$ \\
\hline $\mathrm{T}_{8}$ & $0.00(0.41) \pm 0.00^{\mathrm{e}}$ & $0.00(0.41) \pm 0.00^{d}$ & $2.00(6.69) \pm 1.15^{\mathrm{e}}$ & $5.33(13.17) \pm 1.33^{d}$ & $6.67(14.80) \pm 1.33^{b}$ \\
\hline CV \% & 10.25 & 27.32 & 6.25 & 11.79 & 1.16 \\
\hline Lsd & 2.77 & 13.74 & 6.02 & 14.82 & 1.02 \\
\hline
\end{tabular}

Keul's Range Test). dai=days after infestation, $\mathrm{T}=$ treatment. Values in the parenthesis are angular transformed value

Table 5: Effects of different rates of Malathion dust and Neem seed powder combinations on progeny emerged, percentages of damaged grain, grain weight losses and seed germination after three months of treatment application and infestation

\begin{tabular}{ccccc}
\hline Treatment & $\begin{array}{c}\text { Number of } \\
\text { progeny weevils emerged }\end{array}$ & $\begin{array}{c}\text { Percent damaged } \\
\text { grain }\end{array}$ & Percent grain weight loss & $\begin{array}{c}\text { Percent seed } \\
\text { germination }\end{array}$ \\
\hline $\mathrm{T}_{1}$ & $1.33(1.34) \pm 0.33^{\mathrm{b}}$ & $0.25(0.86) \pm 0.01^{\mathrm{b}}$ & $0.013(0.72) \pm 0.00^{\mathrm{b}}$ & $95.00 \pm 0.58^{\mathrm{a}}$ \\
$\mathrm{T}_{2}$ & $1.67(1.46) \pm 0.33^{\mathrm{b}}$ & $0.25(0.86) \pm 0.01^{\mathrm{b}}$ & $0.010(0.71) \pm 0.00^{\mathrm{b}}$ & $95.00 \pm 0.58^{\mathrm{a}}$ \\
$\mathrm{T}_{3}$ & $1.67(1.46) \pm 0.33^{\mathrm{b}}$ & $0.21(0.84) \pm 0.02^{\mathrm{bc}}$ & $0.010(0.71) \pm 0.00^{\mathrm{b}}$ & $94.67 \pm 0.33^{\mathrm{a}}$ \\
$\mathrm{T}_{4}$ & $1.67(1.46) \pm 0.33^{\mathrm{b}}$ & $0.20(0.84) \pm 0.02^{\mathrm{bc}}$ & $0.013(0.72) \pm 0.00^{\mathrm{b}}$ & $95.67 \pm 0.33^{\mathrm{a}}$ \\
$\mathrm{T}_{5}$ & $1.67(1.46) \pm 0.33^{\mathrm{b}}$ & $0.19(0.83) \pm 0.01^{\mathrm{bc}}$ & $0.010(0.71) \pm 0.00^{\mathrm{b}}$ & $95.00 \pm 0.58^{\mathrm{a}}$ \\
$\mathrm{T}_{6}$ & $1.67(1.46) \pm 0.33^{\mathrm{b}}$ & $0.16(0.81) \pm 0.04^{\mathrm{c}}$ & $0.010(0.71) \pm 0.00^{\mathrm{b}}$ & $95.33 \pm 0.33^{\mathrm{a}}$ \\
$\mathrm{T}_{7}$ & $0.00(0.71) \pm 0.00^{\mathrm{c}}$ & $0.00(0.71) \pm 0.00^{\mathrm{d}}$ & $0.00(0.701) \pm 0.00^{\mathrm{c}}$ & $95.00 \pm 0.58^{\mathrm{a}}$ \\
$\mathrm{T}_{8}$ & $57.00(7.58) \pm 0.57^{\mathrm{a}}$ & $12.06(3.54) \pm 0.07^{\mathrm{a}}$ & $0.820(1.14) \pm 0.01^{\mathrm{a}}$ & $91.00 \pm 0.58^{\mathrm{a}}$ \\
\hline CV\% & $\mathbf{9 . 0 6}$ & $\mathbf{1 . 8 2}$ & $\mathbf{0 . 4 9}$ & $\mathbf{1 . 1 4}$ \\
\hline Lsd & $\mathbf{0 . 3 1 0}$ & $\mathbf{0 . 0 3 5}$ & & $\mathbf{1 . 0 7 9}$
\end{tabular}

Means followed by the same letter within a column are not significantly different from each other at $5 \%$ level of probability (Student-NewmanKeul's Range Test). Values in the parenthesis are square root transformed. $T_{1}=0 \%(0 \mathrm{gm})+100 \%(4 \mathrm{gm}), \mathrm{T}_{2}=10 \%(0.01 \mathrm{gm})+50 \%(2$ $\mathrm{gm}), \mathrm{T}_{3}=20 \%(0.02 \mathrm{gm})+40 \%(1.6 \mathrm{gm}), \mathrm{T}_{4}{ }^{=} 30 \%(0.03 \mathrm{gm})+30 \%(1.2 \mathrm{gm}), \mathrm{T}_{5}=40 \%(0.04 \mathrm{gm})+20 \%(0.8 \mathrm{gm}), \mathrm{T}_{6}=50 \%(0.05 \mathrm{gm})+$ $10 \%(0.4 \mathrm{gm}), \mathrm{T}_{7}=100 \%(0.1 \mathrm{gm})+0 \%$ (standard check) and $\mathrm{T}_{8}=$ Untreated check

Table 6: Residual effects of different rates of Malathion 5\% D and Neem seed powder combinations on the percentage of weevil mortality when grains were re-infested after three months of treatment

\begin{tabular}{cccccc}
\hline \multirow{2}{*}{ Treatment } & \multicolumn{5}{c}{ Percent weevils mortality } \\
\cline { 2 - 6 } & $\mathbf{2 ~ d a i}$ & $\mathbf{4}$ dai & $\mathbf{6}$ dai & $\mathbf{1 2 ~ d a i}$ & $\mathbf{1 8 ~ d a i}$ \\
\hline $\mathrm{T}_{1}$ & $0.67(2.98) \pm 0.67^{\mathrm{cd}}$ & $4.33(11.33) \pm 1.00^{\mathrm{d}}$ & $16.00(23.56) \pm 1.15^{\mathrm{c}}$ & $28.00(31.95) \pm 1.15^{\mathrm{c}}$ & $52.00(46.14) \pm 2.00^{\mathrm{b}}$ \\
$\mathrm{T}_{2}$ & $2.67(9.27) \pm 0.67^{\mathrm{c}}$ & $8.67(17.12) \pm 0.67^{\mathrm{c}}$ & $12.67(20.85) \pm 0.67^{\mathrm{d}}$ & $16.00(23.56) \pm 1.15^{\mathrm{d}}$ & $26.67(31.09) \pm 0.67^{\mathrm{c}}$ \\
$\mathrm{T}_{3}$ & $2.65(7.83) \pm 1.33^{\mathrm{c}}$ & $5.33(13.30) \pm 0.67^{\mathrm{d}}$ & $11.33(19.67) \pm 0.67^{\mathrm{d}}$ & $16.67(24.09) \pm 0.67^{\mathrm{d}}$ & $22.00(27.97) \pm 2.00^{\mathrm{d}}$ \\
$\mathrm{T}_{4}$ & $0.005(7.83) \pm 0.00^{\mathrm{c}}$ & $4.67(12.17) \pm 1.33^{\mathrm{d}}$ & $12.00(20.28) \pm 0.00^{\mathrm{d}}$ & $16.00(23.59) \pm 0.00^{\mathrm{d}}$ & $26.00(30.66) \pm 1.15^{\mathrm{c}}$ \\
$\mathrm{T}_{5}$ & $8.00(16.36) \pm 1.15^{\mathrm{b}}$ & $18.67(25.60) \pm 0.67^{\mathrm{b}}$ & $22.67(28.44) \pm 0.67^{\mathrm{b}}$ & $50.67(45.40) \pm 0.67^{\mathrm{b}}$ & $100.00(89.47) \pm 0.00^{\mathrm{a}}$ \\
$\mathrm{T}_{6}$ & $8.67(17.02) \pm 1.33^{\mathrm{b}}$ & $18.67(25.60) \pm 0.67^{\mathrm{b}}$ & $22.00(27.97) \pm 1.15^{\mathrm{b}}$ & $50.67(45.40) \pm 0.67^{\mathrm{b}}$ & $100.00(89.47) \pm 0.00^{\mathrm{a}}$ \\
$\mathrm{T}_{7}$ & $25.33(30.66) \pm 1.76^{\mathrm{a}}$ & $74.67(59.84) \pm 1.76^{\mathrm{a}}$ & $100.00(89.47) \pm 0.00^{\mathrm{a}}$ & $100.00(89.47) \pm 0.00^{\mathrm{a}}$ & $100.00(89.47) \pm 0.00^{\mathrm{a}}$ \\
$\mathrm{T}_{8}$ & $0.02(0.41) \pm 0.01^{\mathrm{d}}$ & $0.67(2.98) \pm 0.67^{\mathrm{e}}$ & $4.00(11.29) \pm 1.15 \mathrm{e}$ & $4.67(12.42) \pm 0.67^{\mathrm{e}}$ & $2.00(8.13) \pm 0.00^{\mathrm{e}}$ \\
\hline CV \% & $\mathbf{2 7 . 6 2}$ & $\mathbf{7 . 3 4}$ & $\mathbf{3 . 7 9}$ & $\mathbf{2 . 8 3}$ & $\mathbf{2 . 1 4}$ \\
\hline Lsd & $\mathbf{6 . 5 0}$ & $\mathbf{3 . 2 1}$ & $\mathbf{2 . 4 2}$ & $\mathbf{1 . 3 5}$ & $\mathbf{2 . 0 3}$ \\
\hline
\end{tabular}

Means followed by the same letter within a column are not significantly different from each other at $5 \%$ level of probability (Student-NewmanKeul's Range Test). dai=days after infestation. Values in the parenthesis are angular transformed value. $T_{1}=0 \%(0 \mathrm{gm})+100 \%(4 \mathrm{gm}), \mathrm{T}_{2}=$ $10 \%(0.01 \mathrm{gm})+50 \%(2 \mathrm{gm}), \mathrm{T}_{3}=20 \%(0.02 \mathrm{gm})+40 \%(1.6 \mathrm{gm}), \mathrm{T}_{4}=30 \%(0.03 \mathrm{gm})+30 \%(1.2 \mathrm{gm}), \mathrm{T}_{5}=40 \%(0.04 \mathrm{gm})+20 \%(0.8$ $\mathrm{gm}), \mathrm{T}_{6}=50 \%(0.05 \mathrm{gm})+10 \%(0.4 \mathrm{gm}), \mathrm{T}_{7}=100 \%(0.1 \mathrm{gm})+0 \%$ (standard check) and $\mathrm{T}_{8}=$ Untreated check 
Table 7: Residual effects of different rates of Malathion 5\% dust and Neem seed powder combinations on progeny emerged, percentages of grain damaged, grain weight losses and seed germination when the grains was einfested after three months of treatment

\begin{tabular}{ccccc}
\hline Treatment & $\begin{array}{c}\text { Number of progeny } \\
\text { weevils emerged } \\
\mathbf{6 6} \text { dari }\end{array}$ & $\begin{array}{c}\text { Percent } \\
\text { damaged grain } \\
\mathbf{1 5 6} \text { dai }\end{array}$ & $\begin{array}{c}\text { Percent grain } \\
\text { weight loss } \\
\mathbf{1 5 6} \text { dai }\end{array}$ & $\begin{array}{c}\text { Percent seed } \\
\text { germination } \\
\text { 156 dai }\end{array}$ \\
\hline $\mathrm{T}_{1}$ & $47.67(6.94) \pm 0.33^{\mathrm{b}}$ & $9.74(3.20) \pm 0.20^{\mathrm{b}}$ & $1.33(1.35) \pm 0.01^{\mathrm{b}}$ & $88.67 \pm 0.67^{\mathrm{a}}$ \\
$\mathrm{T}_{2}$ & $15.00(3.93) \pm 0.57^{\mathrm{c}}$ & $3.84(2.08) \pm 0.06^{\mathrm{c}}$ & $1.18(1.29) \pm 0.03^{\mathrm{c}}$ & $88.00 \pm 1.15^{\mathrm{a}}$ \\
$\mathrm{T}_{3}$ & $15.33(3.97) \pm 0.33^{\mathrm{c}}$ & $3.51(2.00) \pm 0.13^{\mathrm{d}}$ & $1.15(1.28) \pm 0.01^{\mathrm{c}}$ & $88.61 \pm 0.33^{\mathrm{a}}$ \\
$\mathrm{T}_{4}$ & $14.33(3.84) \pm 0.88^{\mathrm{c}}$ & $3.58(2.01) \pm 0.11^{\mathrm{d}}$ & $1.15(1.28) \pm 0.02^{\mathrm{c}}$ & $91.67 \pm 0.33^{\mathrm{a}}$ \\
$\mathrm{T}_{5}$ & $6.00(2.54) \pm 0.57^{\mathrm{d}}$ & $1.14(1.28) \pm 0.02^{\mathrm{e}}$ & $0.13(0.79) \pm 0.01^{\mathrm{d}}$ & $90.67 \pm 2.40^{\mathrm{a}}$ \\
$\mathrm{T}_{6}$ & $5.67(2.48) \pm 0.33^{\mathrm{d}}$ & $1.17(1.29) \pm 0.02^{\mathrm{e}}$ & $0.14(0.79) \pm 0.00^{\mathrm{d}}$ & $90.00 \pm 3.05^{\mathrm{a}}$ \\
$\mathrm{T}_{7}$ & $1.00(1.22) \pm 0.00^{\mathrm{e}}$ & $0.03(0.72) \pm 0.01^{\mathrm{a}}$ & $0.01(0.72) \pm 0.00^{\mathrm{e}}$ & $90.33 \pm 2.03^{\mathrm{a}}$ \\
$\mathrm{T}_{8}$ & $140.33(11.86) \pm 1.20^{\mathrm{a}}$ & $26.11(5.15) \pm 0.40^{\mathrm{a}}$ & $3.49(1.99) \pm 0.03^{\mathrm{a}}$ & $45.33 \pm 2.85^{\mathrm{b}}$ \\
\hline CV \% & $\mathbf{3 . 3 6}$ & $\mathbf{2 . 0 2}$ & $\mathbf{0 . 9 2}$ & $\mathbf{4 . 0 6}$ \\
\hline LSD & $\mathbf{0 . 2 5 0}$ & $\mathbf{0 . 0 7 2}$ & $\mathbf{0 . 0 1 8}$ & $\mathbf{3 . 4 5 0}$ \\
\hline
\end{tabular}

Means followeMeans followed by the same letter within a column are not significantly different from each other at $5 \%$ level of probability (Student-Newman-Keul's ange Test). dari=days after re-infestation, dai= days after infestation. Values in the parenthesis are square root transformed. $\mathrm{T}_{1}=0 \%(0 \mathrm{gm})+100 \%(4 \mathrm{gm}), \mathrm{T}_{2}=10 \%(0.01 \mathrm{gm})+50 \%(2 \mathrm{gm}), \mathrm{T}_{3}=20 \%(0.02 \mathrm{gm})+40 \%(1.6 \mathrm{gm}), \mathrm{T}_{4}=30 \%(0.03 \mathrm{gm})+$ $30 \%(1.2 \mathrm{gm}), \mathrm{T}_{5}=40 \%(0.04 \mathrm{gm})+20 \%(0.8 \mathrm{gm}), \mathrm{T}_{6}=50 \%(0.05 \mathrm{gm})+10 \%(0.4 \mathrm{gm}), \mathrm{T}_{7}=100 \%(0.1 \mathrm{gm})+0 \%(\mathrm{standard} \mathrm{check})$ and $\mathrm{T}_{8}$ = Untreated check

\section{DISCUSSION}

The study indicated that mixing sorghum with partially grindedchilies (hot pepper) at the rates of $1 \% \mathrm{w} / \mathrm{w}$ and $2 \%$ w/w potentially effective control methods against stored sorghum insect pests and comparable results were observed with malathion $5 \%$ D (Table 3 ). The findings agree with the farmers in sorghum producing areas where they used to mix their produce with partially grindedchilies (hot pepper, personal observation). Some farmers also used to mix sorghum with small seed cereals such as teff and finger millet and layering of tef over sorghum with different proportion. Our finding did not agree with framers 'practice in the case of mixing sorghum with tef and layering tef over sorghum as higher weight of grain damaged per sample and lower weight of undamaged grain per sample were observed from the experiment (Table 2). Prolonged storage of maize admixing with low rates of tef may result in high damage to the produce. According to Abraham (2003), as the rates of tef decreasing $(<30 \% \mathrm{w} / \mathrm{w})$, the efficacy will be decreased even though admixing maize with different rates of tef was better than in the untreated check. Therefore among the farmers practices so far tested mixing sorghum with hot pepper at $1 \% \mathrm{w} / \mathrm{w}$ and $2 \% \mathrm{w} / \mathrm{w}$ resulted in promising effects in protecting storage insect pests and recommended for the farmers.

Significantly higher mortality of adult weevils observed from all combinations of Malathion dust and neem seed powder treatments than the untreated check following 90 dai, are in accordance with previous works. Obeng-Ofori and Amiteye (2003) reported that lower dosages of the oil and pirimiphos-mehyl when combined where highly toxic to adult $S$. zeamais. The same study also reported that a mixture of $1 \mathrm{ml}$ of the oils and 1/16 of recommended rate of pirimiphos-methyl killed over $80 \%$ of the weevils exposed within $24 \mathrm{hr}$. In addition, significantly $(P<0.05)$ lower number of progeny, lower percentages of damaged grain and lower seed weight loss were recorded from all combinations of the treatments following 90 days after infestations. Similarly, the combination of DE and plant extracts at reduced level or with soil bacteria metabolites, formulated as "All Natural" and "Spindeba", prevented progeny emergence of Prostephanus truncatus at 50-100 ppm (Stather and Credland, 2003). A reduced level of the combinations provided adequate protection of maize from maize weevils for more than six months (Credland, 2003). Ulrich and Mewis (2000) showed that combination of DE fossil shield $\left(1 \mathrm{gm} \mathrm{kg}^{-1}\right)$ and a commercial neem product Azal-T/S $\left(1 \mathrm{gm} \mathrm{kg}^{-1}\right)$ resulted in higher mortality of weevils, low progeny emergence and effective control of $T$. castaneum and $S$. oryzae for more than three months. Arthur (2002) reported that significantly high mortality and low progeny weevils emerged from insecticidal pyrazole applied at rates of 7.5 and $10 \mathrm{ppm}$ either alone or in combination with deltamethrin, piperonyl butoxide and chloropyriphos-methyl against the red flour beetles.

The persistence of the treatments following 90 days after infestation showed that mortality in all of the treatment combinations were significantly higher than the untreated check. However, the effects on the mortality were gradual in all of the combinations of the treatments, except for the Malathion dist rates at $40 \%$ and $50 \%$ combinations with NSP at $20 \%$ and $10 \%$, respectively. The number of progeny, percentages of damaged grain, and grain weight loss were significantly lower in the above-mentioned two rates. These are in accordance with the reports of (Srrenarayanan et al., 1999) all the combinations of malathion and olive oil resulted in effective control of the maize weevil the effectiveness was similar to recommended rates following sixty days after infestation. On the other hand, decreased potency of NSP with increased time after infestation is in line with the results of many authors indicated that the effectiveness of plant powder decreases with increasing time after infestation. The study also confirmed that, applications of NSP effectively controlled for 3 months and further applications will be required after this time. The rates of Malathion dust at $40 \%$ and $50 \%$ combinations with neem seed at $20 \%$ and $10 \%$ effectively protect maize from the maize weevils for almost five months. The two higher rates of Malathion dust combined with Neem seed effectively controlled the weevil for about five months. The efficacy of neem seed powder declined with time and combinations, which had higher rates of Malathion dust, provided better protection to the maize grain than the other rates of combinations. The current study clearly showed that use of mixtures of synthetic insecticide and botanicals effectively controlled the maize weevil and prolonged their persistence than the use of the individual materials. 


\section{Ahmed lbrahim}

\section{CONCLUSION}

Among the farmers practices so far tested, mixing sorghum with partially grindedchilies (hot pepper) at the rate of $2 \% \mathrm{w} / \mathrm{w}$ and $1 \% \mathrm{w} / \mathrm{w}$ have showed promising effects against stored sorghum insect pests than the others treatments and equivalent results were recorded with standard check in controlling insect pests in stored sorghum. The period of protection lasted for about six months. Mixing grindedchilies at the rate of $1 \% \mathrm{w} / \mathrm{w}$ and $2 \% \mathrm{w} / \mathrm{w}$ can be used to protect stored sorghum insect pests.

Following 156 days after infestation, Malathion dust at $40 \%$ and $50 \%$ combined with Neem seed powder at $20 \%$ and $10 \%$, respectively, provided significant protection to the maize grain next to the standard check. From these studies, it can be concluded that combinations are better than single treatment. Combinations of Malathion and neem seed powder at $40 \%+20 \%$ and $50 \%+10 \%$ can be used to protect maize from the maize weevil.

\section{Conflict of Interest}

Conflict of interest non declared.

\section{Acknowledgments}

I am very grateful to field assistance and field supervisor of Crop Protection Research Division of Bako Agricultural Research Center for their immeasurable and wholehearted efforts they made in managing the field. My special thanks go to Teshome Bogale and Mulu Dia for their enthusiastic efforts they made in collecting the data.

\section{REFERENCES}

Abbot, W.S. (1925). A method of computing the effctiveness of insecticides. Journal of Economic Entomology 18: 265267 .

Arthur, F.H. (2002). Efficacy of ethiprol applied alone and in combination with conventional insecticides for protection of stored wheat and stored corn. Journal of Economic Entomology 95:1314-1318.

Beyene, S, Benti, T. and Abera, D. (1996). The impact of post harvest technology on productivity grains of maize hybrids in Ethiopia. Pp. 32-26. In: J.K. Ransom, A.F.E.
Sci. Technol. Arts Res. J., Jan-March 2015, 4(1): 50-56

Palmer, B.T. Zambezi, Z.O. Mduruma, S.R. Waddington, K.V. Pixley and D.C. Jewell (eds.) Maize productivity gains through research and technology dissemination. Proceeding of the Fifth Eastern and Southern Africa Regional Maize Conference held in Arusha, Tanzania, 3-7 June 1996, Addis Abeba, Ethiopia, CIMMYT.

Boxall, R.A. (1986). A critical review of the methodology for assessing farm level grain losses after harvest. Report of the TDR G191,139pp.

Dobie, P. (1984). Biological methods for integrated control of insect and mites in tropical stored products. The use of resistance varieties. Tropical Stored Products Information 48: 4-8.

Dobie, P. (1977). The contribution of Tropical Stored Products Center to the study to insect resistance in stored maize. Tropical Stored Products Information 99(34):7-21.

Emana, G. and Assefa, G.A. (1998). Arthropods pests of stored maize in Sidama zone: Economic importance and management practices. Pest Management Journal of Ethiopia 2(1\&2): 26-35.

Obeng- Ofori, D. and Amiteye, S. (2003). Efficacy of mixing vegetable oils with primiphos-methyl against the maize weevils, Sitophilus zeamais Motschulsky in stored maize. Jornal of Stored Product Research 41: 57-66.

Stather, T.E. and Credland, P.F. (2003). Combinations to enhance the efficacy of Diatomaceous earth against the larger grain borer, Prostephanus truncatus (Horn). Advance in stored product protection. Proceeding of the $8^{\text {th }}$ International Working Conference on Stored Product Protection, York, UK, 22-26 July 2002.

Ulrich Ch and Mewis, L. (2000). Treatments of rice with neem and diatomaceous earth for controlling stored product Coleoptera, Sitophilus oryzae and Tribolium castaneum. Journal of Pest Science 73: 37-40.

Wright, V.F., Millis, R.B. and Willcut, B.J. (1989). Methods for culturing stored grain insects, pp.74-83. In: Toward Insect Resistance Maize for the Third World: Proceeding of the International Symposium and Methodologies for Developing Host Plant Resistance to Maize Insect. CIMMYT, Mexico, 9-14 March 1987. CIMMYT, Mexico D.F. 